\title{
PERAN KADER KESEHATAN DALAM MENINGKATKAN KUNJUNGAN IBU BALITA KE POSYANDU DI WILAYAH KERJA PUSKESMAS TANJUNG KARANG KOTA MATARAM
}

\author{
Sukardin $^{1}$, Chairun Nasirin ${ }^{2}$ \\ ${ }^{1,2)}$ Pengajar Sekolah Tinggi Ilmu Kesehatan (STIKES) Mataram \\ Email:kardinsakti@yahoo.co.id
}

\section{INTISARI}

Pos Pelayanan Terpadu (Posyandu) adalah unit pelayanan kesehatan yang diselenggarakan oleh masyarakat untuk masyarakat, dengan dukungan teknis petugas Puskesmas. Penelitian ini bertukuan untuk hubungan antara peran kader terhadap peningkatan kunjungan ibu Balita di wilayah kerja Puskesmas Tanjung Karang Kota Mataram.

Design penelitian yang digunakan adalah deskriptif korelasional dengan pendekatan cross sectional. Instrumen yang digunakan kuesioner observasi, dokumentasi dan wawancara. Populasi penelitian adalah semua Ibu yang mempunyai balita yang berada di wilayah kerja Puskesmas Tanjung Karang dan teknik sampel yang digunakan adalah purposive sampling. Analisa data dalam penelitian ini menggunakan adalah uji Chi Square dengan tingkat kemaknaan 0,05 (5\%).

Berdasarkan hasil uji statistic menggunakan uji Chi Square dengan bantuan program SPSS untuk mencari hubungan peran kader dengan kunjungan Ibu balita ke posyandu di wialyah kerja Puskesmas Tanjung Karang diperoleh $\chi^{2}=19,68, P$ Value $=$ 0,001 . Hal ini berarti bahwa terdapat hubungan yang signifikan antara peran kader dengan kunjungan ibu balita ke posyandu di wilayak Kerja Puskesmas Tanjung Karang Kota Mataram. Diharapkan kader kesehatan untuk lebih aktif memberikan informasi serta koordinasi antara petugas dalam kegiatan posyandu.

Kata kunci : Posyandu, Peran Kader, Balita, Kunjungan Ibu

\section{LATAR BELAKANG}

Salah satu penyebab derajat kesehatan masyarakat di Indonesia masih rendah adalah belum dimanfaatkannya sarana pelayanan kesehatan secara optimal oleh masyarakat, termasuk posyandu. Pos Pelayanan Terpadu (Posyandu) berperan dalam menumbuhkan peran serta masyarakat untuk mendekatkan terhadap jangkauan pelayanan kesehatan primer. Semakin tinggi masyarakat mendapat pelayanan kesehatan, semakin meningkat derajat kesehatan masyarakat oleh dan untuk masyarakat, maka salah satu keberhasilan dalam pelaksanaan posyandu diharapkan memperbaiki atau meningkatkan derajat Kesehatan masyarakat (Budioro, 2000). Posyandu merupakan salah satu bentuk Upaya Kesehatan Bersumber Daya Masyarakat (UKBM) yang dikelola dan diselenggarakan dari, oleh, untuk dan bersama masyarakat dalam penyelenggaraan pembangunan kesehatan, guna memberdayakan masyarakat dan memberikan kemudahan kepada masyarakat dalam memperoleh pelayanan kesehatan dasar, utamanya untuk mempercepat penurunan angka kematian ibu dan bayi (Kemenkes RI, 2011).

Posyandu memiliki 5 program khusus yaitu KIA, KB, Imunisasi, Gizi, dan penanggulangan diare. Selain itu juga pelaksanaan kegiatan posyandu mengacu pada sistim 5 langkah, yang masing- 
masing langkah tersebut adalah dimulai dari pendaftaran, penimbangan, pengisian KMS, penyuluhan dan pelayanan kesehatan. Hal ini sesuai dengan jumlah kader yang minimal terdapat 5 orang kader disetiap kegiatan posyandu (Kemenkes RI, 2011). Posyandu dipandang sangat bermanfaat bagi masyarakat, akan tetapi keberadaannya di masyarakat kurang berjalan dengan baik, sehingga pemerintah mengadakan program revitalisasi Posyandu (Notoatmodjo, 2007). Beberapa kendala yang terjadi terkait dengan kunjungan balita keposyandu adalah tingkat pemahaman keluarga terhadap manfaat posyandu. Keaktifan ibu pada setiap kegiatan di Posyandu akan berpengaruh pada perkembangan status gizi anak balita. Dimana salah satu tujuan dari Posyandu adalah memantau peningkatan status gizi masyarakat terutama anak balita dan ibu hamil. Agar tercapai tujuan dari Posyandu maka diharapkan ibu yang memiliki anak balita hendaknya aktif dalam pemanfaatan Posyandu agar status gizinya terpantau (Kristiani, 2009).

Berdasarkan data Riskesdas 2010, 50 persen Balita di Indonesia tidak melakukan penimbangan teratur di posyandu. Hal ini dikarenakan ketidakhadiran orang tua dalam kegiatan posyandu. Riset ini sekaligus menunjukkan kecenderungan cara pandang orang tua yang merasa anaknya tidak perlu lagi dibawa ke posyandu seiring dengan pertambahan umur (Riskesdas, 2010). Sedagakan di Kota Mataram, pada tahun 2015 tingkat partisipasi masyarakat terhadap kegiatan posyandu sebesar 58,45\%. Kunjungan tertinggi adalah Puskesmas Karang Pule $(74,65 \%)$ sedangkan terendah adalah Puskesmas Tanjung Karang sebesar 43,32\% (Dinas Kesehatan Kota Mataram, 2015). Pencapaian tersebut masih jauh dari target nasional yaitu sebesar $80 \%$.

Kunci keberhasilan pengembangan program posyandu adalah tumbuhnya partisipasi masyarakat (Syarifudin, 2009). Menurut Notoatmodjo (2010), mencari pelayanan kesehatan dapat terwujud dalam tindakan jika hal itu dirasakan sebagai kebutuhan sedangkan kebutuhan merupakan dasar dari terjadinya motivasi. Semakin tinggi motivasi, semakin tinggi intensitas perilakunya (Asnawi, 2007). Penelitian Imam dan Nova (2012), menyimpulkan ada hubungan antara motivasi ibu dengan tingkat kehadiran balita di posyandu.

Selain itu keberhasilan posyandu tak lepas dari kerja keras kader yang dengan sukarela mengelola posyandu di wilayahnya masing-masing. Kurangnya pengetahuan, pelatihan dan pembinaan keterampilan memadai bagi kader menyebabkan kurangnya pemahaman tugas kader, lemahnya informasi serta koordinasi antara petugas dalam kegiatan posyandu juga dapat mengakibatkan kurangnya tingkat kehadiran balita ke posyandu. Hal ini sejalan dengan hasil penelitian yang di lakukan oleh Sukardin, dkk (2017) bahwa ada ada hubungan pengetahuan dan motivasi kader posyandu dengan frekuensi kunjungan ibu balita di posyandu wilayah kerja Puskesmas Wera Kabupaten Bima. Orang yang berpengetahuan tinggi akan memberikan respon yang lebih rasional terhadap informasi yang datang dan alasan berfikir sejauh mana keuntungan yang mungkin akan mereka peroleh dari gagasan tersebut (Notoatmodjo, 2003). Kelangsungan posyandu tergantung dari partisipasi masyarakat itu sendiri. Rendahnya peran serta masyarakat untuk datang ke posyandu disebabkan adanya beberapa faktor. Faktor tersebut antara lain, umur balita, jumlah anak, jarak dari rumah ke posyandu terlalu jauh, kurangnya menarik sarana prasarana di posyandu, dan kurangnya pengetahuan ibu tentang pentingnya berkunjung ke posyandu (Ismawati, 2010). Faktor yang mempengaruhi perilaku kader dalam pelaksanaan posyandu, yaitu faktor 
eksternal dan internal. Faktor eksternal dari sosial budaya, dukungan tokoh masyarakat, peran petugas kesehatan, pengaruh keluarga, dan kebijakan pemerintah, Sedangkan faktor internal meliputi pendidikan, sikap, motivasi, dan pekerjaan. Disisi lain faktor pekerjaan yang paling mendominasi ketidakefektifan kader posyandu (Rumpiati, 2011). Penelitian Isnaini dan Endro (2015), menyimpulkan ada hubungan antara peran kader dengan tingkat kehadiran balita di posyandu. Berdasarkan uraian di atas maka perlu diteliti bagaimana peran kader posyandu dalam meningkatkan kunjungan balita ke posyandu. Berdasarkan uraian di atas maka peneliti tertarik untuk melihat bagaimanakah peran kader posyandu dalam meningkatkan kunjungan balita ke posyandu di Wilayah kerja Puskesmas Tanjung Karang Kota Mataram.

\section{BAHAN DAN METODE}

Penelitian ini menggunakan studi korelasional dengan pendekatan cross sectional study. Sampel dalam penelitian ini adalah semua ibu yang memiliki balita sebanyak 79 orang. Teknik sampling yang digunakan adalah nonprobability sampling dengan purposive sampling yaitu tehnik penentuan sampel berdasarkan kebetulan, yaitu suatu tehnik pengambilan sampel untuk tujuan tertentu. Instrumen yang di gunakan dalam penelitian ini adalah yang pertama adalah kuesioner dan observasi digunakani untuk memperoleh data tentang peran kader di posyandu serta data demografi ibu balita. kemudian untuk melihat kunjungan ibu balita ke posyandu menggunakan data sekunder dari Puskesmas Tanjung Karang kota Mataram. Uji statistic Chi square digunakan untuk melihat hubungan antara perang kader Kesehatan terhadap kunjungan ibu balita di Puskesmas Tanjung Karang kota Mataram.

\section{HASIL DAN PEMBAHASAN}

\section{HASIL}

1. Tabel 1. Distribusi responden berdasarkan kunjungan ibu balita ke posyandu di wilayah kerja Puskesmas Tanjung Karang Kota Mataram.

\begin{tabular}{|l|l|c|c|}
\hline No & $\begin{array}{l}\text { Kunjungan ibu balita } \\
\text { ke poyandu }\end{array}$ & $\mathrm{F}$ & $\%$ \\
\hline 1. & Teratur & 34 & 43,04 \\
\hline 2. & Tidak teratur & 45 & 56.96 \\
\hline & Total & 79 & 100 \\
\hline
\end{tabular}

Berdasarkan table 1, didapatkan bahwa Sebagian besar ibu balita (56,96\%) di wilayah kerja Puskesmas Tanjung Karang kunjungan ke posyandu tidak teratur.

2. Tabel 2. Distribusi responden berdasarkan peran kader di wialayah kerja Puskesmas Tanjung Karang Kota Mataram.

\begin{tabular}{|l|l|c|c|}
\hline No & Peran kader & F & $\%$ \\
\hline 1. & Baik & 40 & 50,63 \\
\hline 2. & Cukup & 26 & 32,91 \\
\hline 3. & Kurang & 13 & 16,46 \\
\hline & Total & 79 & 100 \\
\hline
\end{tabular}

Berdasarkan table 1, didapatkan bahwa 50,56\% responden mengatakan peran kader baik, dan hanya $16,46 \%$ responden yang mengatakan peran kader kurang.

3. Tabel 3. Distribusi peran kader dalam meningkatkan kunjungan ibu balita di wilayah kerja Puskesmas Tanjung Karang Kota Mataram.

\begin{tabular}{|c|c|c|c|c|c|c|c|c|}
\hline \multirow{3}{*}{$\begin{array}{c}\text { Peran } \\
\text { Kader } \\
\text { Posyandu }\end{array}$} & \multicolumn{4}{|c|}{$\begin{array}{c}\text { Kunjungan ibu balita ke } \\
\text { Posyandu }\end{array}$} & \multirow{2}{*}{\multicolumn{2}{|c|}{ Total }} & \multirow{3}{*}{$\chi^{2}$} & \multirow{3}{*}{$\begin{array}{c}P \\
\text { Value }\end{array}$} \\
\hline & \multicolumn{2}{|c|}{ Teratur } & \multicolumn{2}{|c|}{$\begin{array}{c}\text { Tidak } \\
\text { teratur }\end{array}$} & & & & \\
\hline & $\mathrm{F}$ & $\%$ & $\mathrm{~F}$ & $\%$ & $\mathrm{~F}$ & $\%$ & & \\
\hline Baik & 19 & 24,05 & 21 & 26,58 & 40 & 50,63 & \multirow{4}{*}{19,68} & \multirow{4}{*}{.001} \\
\hline Cukup & 11 & 13,92 & 15 & 18,99 & 26 & 32,91 & & \\
\hline Kurang & 4 & 5,06 & 9 & 11,39 & 13 & 16,46 & & \\
\hline total & 34 & 43,04 & 45 & 56,96 & 79 & 100 & & \\
\hline
\end{tabular}

Tabel 3, berdasarkan hasil uji Chi Square dengan bantuan program SPSS untuk mencari hubungan peran kader dengan kunjungan Ibu balita ke posyandu di wialyah kerja Puskesmas Tanjung Karang diperoleh $\chi^{2}=19,68$, $P$ Value $=0,001$. Hal ini berarti bahwa 
terdapat hubungan yang signifikan antara peran kader dengan kunjungan ibu balita ke posyandu di wilayak Kerja Puskesmas Tanjung Karang Kota Mataram.

\section{PEMBAHASAN}

1. Kunjungan ibu Balita ke Posyandu Berdasarkan hasil penelitian di dapatkan Sebagian besar $(56,96 \%)$ responden tidak teratur membawa anaknya ke posyandu. Menurut analisis peneliti banyaknya ibu yang beraktivitas di rumah sebagai ibu rumah tangga sebagian besar menghabiskan waktunya untuk pekerjaan rumah danpekerjaankantor yang menyebabkan semakin kecil kemungkinan ibu untuk datang ke Posyandu disebabkan karena jadwal Posyandu bersamaan dengan pekerjaannya.

Dari hasil penelitian menunjukkan bahwa dari 76 ibu balita, dapat dilihat bahwa lebih dari separohIbu Balita Bekerja yaitu sebesar 56.6\%. Bekerja adalah melakukan pekerjaan dengan maksud memperoleh atau membantu memperoleh pendapatan atau keuntungan dan lamanya bekerja paling sedikit satu jam secara terus menerus, termasuk pekerjaan keluarga tanpa upah yang membantu dalam suatu usaha atau kegiatan ekonomi. Cenderung memilih bekerja disektor informal dan ini mejadi hambatan bagi ibu untuk ikut membagi waktu dalam kegiatan sosial diantaranya Posyandu (Anik S, 2013).

Sulistiyanti Anik, Risqi Dewi Untariningsi.2013. Hubungan Status Pekerjaan dengan Keaktifan Ibu menimbang Balita di Posyandu Puri waluyo DesaGebang kecamatan Masaran Kabupaten sragen.

Kunjungan balita ke Posyandu yang paling baik adalah rutin tiap bulan atau
12 kali pertahun dengan batasan minimal 10 kali setahun. Dan pada frekuensi kunjungan balita yang kurang dari 10 kali setahun dianggap masih rawan sedangkan bila frekuensi 10 kali atau lebih sampai satu tahun dianggap baik (Depkes RI, 2016).

2. Peran Kader Posyandu

Hasil penelitian menunjukkan bahwa sebanyak 40 orang kader $(50,63 \%)$ peran kader dalam kategori baik. Ini berarti bahwa sebagian besar kader posyandu telah mampu melakukan tugas dan perannya dengan baik. Keberhasilan posyandu tidak terlepas dari peran kader Kesehatan dalam mengelola posyandu (Malahayani, 2015). Namun, ada sebagian kecil $(16,46 \%)$ kader posyandu dalam kategori kurang. Berdasarkan hasil observasi yang dilakukan oleh peneliti, pelaksanaan meja 4 kader jarang melaksakan penyuluhan. Penyuluhan kesehatan adalah pengetahuan dan kemampuan seseorang melalui teknik praktik belajar atau instruksi dengan tujuan mengubah atau mempengaruhi perilaku manusia baik secara individu, kelompok maupun masyarakat untuk meningkatkan kesadaran akan nilai kesehatan sehingga dengan sadar mau mengubah perilakunya menjadi perilaku hidup sehat. Kemudian dalam memberitahukan hari dan jam buka posyandu kepada ibu pengguna posyandu masih jarang dilakukan oleh kader. Ini disebabkan karena jumlah kader yang lebih sedikit di bandingkan dengan jumlah Ibu yang datang ke posyandu, selain itu kader juga tidak memiliki keahlian yang sama seperti yang dimiliki oleh tenaga kesehatan. Menurut Runjati (2011) salah satu tugas kader yaitu memberitahukan hari dan jam buka posyandu kepada ibu pengguna posyandu (ibu hamil, ibu yang mempunyai bayi dan anak balita, 
serta ibu usia subur) sebelum hari buka posyandu. Berdarkan hasil penelitian peran kader dalam memberitahukan hari dan jam buka posyandu kepada ibu pengguna posyandu juga terdapat kategori kurang, dikarenakan kader posyandu tersebut tidak melakukan peran tersebut karena menganggap jadwal posyandu sudah terjadwal, sehingga tidak diingatkan lagi pada ibu pengguna posyandu, seharusnya kader kesehatan tetap mengingatkan agar sasaran posyandu dapat mencakup semua masyarakat di wilayah posyandu sehingga sasaran posyandu dapat menyeluruh.

Peranan kader sangatlah penting, karena kader bertanggung jawab dalam pelaksanaan posyandu. Jika kader tidak aktif, maka pelaksanaan posyandu juga akan menjadi tidak optimal. Peranan kader sangat mempengaruhi tingkat keberhasilan program posyandu khususnya dalam pemantauan tumbuh kembang anak dan kesehatan ibu. Menurut Martinah (2008) hanya $40 \%$ kader yang aktif dalam kegiatan posyandu di Indonesia. Oleh karena itu, perlu diupayakan langkah dalam memberdayakan kader agar lebih profesional dalam memantau tumbuh kembang anak dan kesehatan ibu, serta membangun kemitraan masyarakat untuk meningkatkan dukungan dan memanfatkan posyandu secara optimal. Sehingga pemberdayaan kader sangat penting untuk mengoptimalkan Revitalisasi Posyandu.

3. Peran kader Posyandu dalam meningkatkan kunjungan ibu Balita ke Posyandu di wialayah kerja Puskesmas Tanjung Karang Kota Mataram.

Hasil uji Chi Square diperoleh $\chi^{2}=19,68, P$ Value $=0,001$. Hal ini berarti bahwa terdapat hubungan yang signifikan antara peran kader dengan kunjungan ibu balita ke posyandu di wilayak Kerja Puskesmas Tanjung Karang Kota Mataram. Hubunganngan ini bersifat searah, artinya semakin baik peran kader makan semakin teratur ibu datang ke posyandu. Berdasarkan hasil penelitian dapat diketahui bahwa sebagian besar kader masih ada yang belum mampu melaksanakan perannya sehingga masih ada Ibu yang tidak teratur datang ke posyandu. Adanya sebagian peran yang belum mampu dilakukan dengan baik menyebabkan masyarakat kurang percaya pada kegiatan posyandu yang dilakukan oleh kader yang berdampak pada turunnya jumlah Ibu yang datang ke posyandu. Sedangkan kunjungan Ibu ke posyandu sangat penting karena kunjungan Ibu, bayi dan balita ke posyandu adalah datangnya Ibu, bayi dan balita ke posyandu untuk mendapatkan pelayanan kesehatan misalnya penimbangan, imunisasi, penyuluhan gizi, dan sebagainya (Agus, 2010).

Banyak faktor yang menyebabkan tidak teraturnya Ibu datang ke posyandu, seperti Umur Ibu, tingkat pengetahuan, pendidikan, pekerjaan dan peran kader sendiri. Dari faktor umur dapat diketahui bahwa sebagian besar Ibu masih berada pada usia produktif (20-35 tahun), sehingga masih ada kecenderungan untuk mengabaikan tugasnya dalam membawa balitanya ke posyandu karena para Ibu muda tersebut ada yang memiliki pekerjaan sebagai PNS. Statusnya sebagai PNS membuat Ibu tidak memiliki waktu untuk membawa balitanya ke posyandu. Selain itu peran petugas kesehatan dan kader kesehatan yang masih kurang dalam memberikan pelayanan seperti kurang disiplin 
(terlambat dari jadwal dalam melaksanakan kegiatan posyandu), sedikitnya tenaga kesehatan yang mendampingi kader saat posyandu, kader yang kurang terampil dalam melakukan kegiatan posyandu.

Pendidikan orang tua merupakan salah satu faktor yang penting dalam tumbuh kembang balita, karena dengan pendidikan yang baik, maka orang tua dapat menerima segala informasi dari luar terutama tentang cara pengasuhan balita yang baik, bagaimana menjaga kesehatan balitanya, pendidikannya dan sebagainya (Soetjiningsih, 2000). Aspek sosio ekonomi akan berpengaruh pada partisipasi masyarakat di Posyandu. Semua Ibu yang bekerja baik di rumah atau luar rumah, keduanya akan tetap meninggalkan balita-balitanya untuk sebagian besar waktu (Neil Niven, 2000:253).

Selain itu kader di posyandu juga sangat berperan penting karena posyandu merupakan salah satu bentuk fasilitas yang dimanfaatkan oleh masyarakat hal ini dapat dilihat dari beberapa keluhan masyarakat yang disampaikan kepada peneliti, bahwa salah satu faktor yang membuat Ibu malas datang pada kegiatan posyandu adalah karena kader sering terlambat pada saat memberikan pelayanan pada posayandu. Hal ini karena Posyandu yang dilakukan oleh kader Posyandu yang terampil akan mendapat respon positif dari Ibu-Ibu balita sehingga kader tersebut ramah dan baik. Kader Posyandu yang ramah, terampil dalam memberikan pelayanan kesehatan dapat menyababkan Ibu-Ibu balita rajin datang dan memanfaatkan pelayanan kesehatan di Posyandu (Yon Ferizal dan Mubasysyir Hasanbasri, 2007:10).

Dimana kader berasal dari anggota masyarakat, bekerja sukarela, mampu melaksanakan kegiatan, mampu menggerakan masyarakat untuk ikut serta dalam kegiatan, bekerja sukarela, mampu melaksanakan kegitan, mampu menggerakan masyarakat untuk ikut serta dalam kegiatan Posyandu. Kader mempunyai peranan langsung dan tidak langsung dalam melaksanakan kegiatan. Kader juga memiliki tanggung jawab dalam mempersiapkan pelaksanaan UPGK di Posyandu, dimana sehari sebelumnya, semua Ibu hamil, Ibu menyusui, Ibu balita diberi tahu akan ada kegiatan di Posyandu. Tidak lupa mencatat sasaran Posyandu dan mempersiapkan alat dan bahan yang diperlukan. Bila ada alat yang belum tersedia, dapat meminjam, minta pada petugas atau membuat sendiri dan pembagian petugas diantara para kader dibantu Ibu-ibu yang lain (Tim UPGK, 2000). Akan tetapi, sebagian dari tanggung jawa tersebut masih ada yang tidak dilakukan dengan baik oleh petugas kader terutama kesipan kader dalam melaksanakan kegiatan posyandu seperti keterlambatan datang kader dari jadwal yang telah disepakati, ketersediaan yang masih kurang dan pembagian tugas kader yang dilakukan pada saat kegiatan posyandu sedang dilaksanakan. hal ini membuat masyarakat terutama sasaran posyandu (Ibu Hamil, Ibu menyusui, Bayi, Balita dan Ibu yang mempunyai balita) tidak teratur datang ke posyandu.

\section{KESIMPULAN DAN SARAN}

Berdasarkan hasil uji statistic menggunakan ujii Chi Square diperoleh $\chi^{2}$ $=19,68, P$ Value $=0,001$. Hal ini berarti bahwa terdapat hubungan yang signifikan antara peran kader dengan kunjungan ibu balita ke posyandu di wilayak Kerja 
Puskesmas Tanjung Karang Kota Mataram.

Diharapkan agar petugas menyediakan waktu untuk kegiatan posyandu pada waktu yang telah ditetapkan dan disepakati dengan masyarakat. Bagi ibu balita untuk memamfaatkan posyandu secara rutin setiap bulannya sebagai wadah dalam memantau tumbuh kembang balitanya
DAFTAR PUSTAKA

Agus. 2010. Pedoman Kerja Lapangan Utuk Menarik Minat Ibu Dan Balita Berkunjung Ke Posyandu. Bandung: Rosdakarya.

Asnawi, S. (2007). Teori Motivasi dalam Pendekatan Psikologi Industri dan Organisasi. Jakarta: Studi Press

Bulak Lor Wilayah Kerja Puskesmas Jatibarang. Jurnal Kesehatan Masyarakat, Vol.1, No.2.

Budioro. 2000. Pengatar Kesehatan Masyarakat. Semarang : UNDIP

Dusun Belahan Wilayah Kerja Puskesmas Puri. Jurnal Penelitian. Mojokerto: Stikes Bina Sehat PPNI.

Dinas Kesehatan Kota Mataram. 2015. Profil Kesehatan Kota Mataram tahun 2015

Imam Z dan Nova A,J. (2012). Hubungan Antara Motivasi Ibu dengan Kunjungan Balita ke Posyandu di

Isnaini R, dan Endro A. (2015). Faktor yang Berhubungan dengan Kunjungan Balita ke Posyandu Desa

Ismawati, Cahyo. 2010. Posyandu dan Desa Siaga. Yogyakarta: Nuha Medika.

Kementerian Kesehatan RI, 2011. Buku Pegangan Kader Posyandu. Jakarta, Indonesia.

Kemenkes RI. 2016. Pedoman Umum Pengelolaan Posyandu. Jakarta

Malahayati, N. (2015). Hubungan Peran Kader dan Dukungan Keluarga terhadapRendahnya Kunjungan Bayi dan Balita ke Posyandu di DesaBuket Selamat Kecamatan Sungai RayaKabupaten Aceh Timur. Jurnal Bina Nusantara. 3(2), 78-86

Neil Niven. 2000. Pekerjaan Dan Sosial Ekonomi Keluarga. Jakarta : Binapura Aksara

Notoatmodjo. (2010). Ilmu Perilaku Kesehatan. Jakarta: Rineka Cipta.

Notoatmodjo,2003, Pendidikan dan Perilaku Kesehatan, Jakarta: Rhineka Cipta, 
Rumpiati. 2011. Hubungan Peran Kader dengan Kunjungan Balita dalam Pelaksaan Posyandu. Akademi Kebidanan Muhammadiyah Madiun.

Runjati. 2011. Asuhan Kebidanan Komunitas. Jakarta: EGC

Soetjiningsih. 2000. Pendidikan Keluarga. Jakarta: Asdi Maha Satya.

Syafrudin. (2009). Buku Ajar Ilmu Kesehatan Masyarakat untuk Mahasiswa Kebidanan. Jakarta: CV Trans Info Media

Sukardin, Khadafi A, Cahyono W. 2017. Hubungan Pengetahuan Kader Tentang Posyandu Dan Motivasi Kader Posyandu Dengan Frekuensi Kunjungan Ibu Balita Di Posyandu Wilayah Kerja Puskesmas Wera Kabupaten Bima. PrimA;Jurnal Ilmiah Ilmu Kesehatan Mataram.STIKES Mataram.

Tim UPGK. 2000. Buku Kader Usaha Perbaikan Gizi Keluarga. Jakarta. Tim UPGK Indonesia.

Yon Ferizal dan Mubasysyir Hasanbasri. 2007. Petugas Posyandu. Yogyakarta : Rineka Cipta 